\title{
Japan's New Defense Policy: Identity Change or Strategic Shift
}

\author{
Nutthathirataa Withitwinyuchon
}

\begin{abstract}
Many view Japan's latest move to reinterpret its postwar peaceful constitution with inevitable wariness that the nation identity as a pacifist country has totally changed and that Japan is now returning to militaristic past. Analyzing Japan's defense policies from the postwar period until present through lens of constructivism theory, this paper argues that Japan's national identity has not drastically changed but gradually transformed over the past 60 years in accordance with ongoing changes in international security environment. Japan's new defense posture achieved through reinterpretation of the constitution is arguably a combined consequence of both strategic shift and incremental change in Japan's national identity. However, this ongoing transformation in identity from a peaceful state in the Cold War era to a normal state in the post-Cold War period does not mean that Japan has totally shaken off its antimilitarism culture and is pursuing militarism.
\end{abstract}

Index Terms-Identity, Japan, reinterpretation of constitution, security policy.

\section{INTRODUCTION}

Japan's cabinet approved on 1 July a reinterpretation of its so-called pacifist constitution, paving the way for the Japan Self-Defense Forces (SDF) to help defend foreign countries under what is known as collective self-defense. This means Japanese forces would be able to fight overseas alongside with its allies were they to come under attack. Following the cabinet's approval for lifting the ban on the right to collective self-defense, Japan held large-scale military drills at the foothills of Mount Fuji between 19-24 Augusts. The military exercises, which involved fighter jets, attack helicopters and tanks, showcased the ability to defend or retake islands in and around the disputed East China Sea. [1] While Washington welcomed the reinterpretation as it happened just when the U.S. is seeking to redistribute military expenses in the region in the face of China's rise, the move increased concerns of Japan's neighboring countries, which in turn could put regional stability at risk.

One possible question could be raised here following this bold movement: is the regional superpower departing from the postwar antimilitarism culture and inching towards militaristic state? Japan's image of war-denouncing country has largely reflected in its postwar constitution, which was drawn up under the U.S.-led Allied occupation and enacted in May 1947. The consistent practice of this antimilitarism culture in line with the postwar peaceful constitution has thus far constructed Japan's national identity as a pacifist country.

Manuscript received September 9, 2014; revised November 28, 2014.

Nutthathirataa Withitwinyuchon is with the Department of Politics, University of Otago, New Zealand (e-mail: witnu613@student.otago.ac.nz).
However, Japan's new defense policy is possibly showing a certain extent of change in its national identity and/or strategy adaptation. To shed light on this issue, this paper will attempt to explain Japan's recently contentious move through lens of constructivism approach.

\section{NATIONAL IDENTITY}

A definition of national identity defined by Rex Li is "a form of collective identity, whereby the identity of a group of people is defined and shaped by its internal cohesion and external relationship with other groups of people." [2] National identity does not emerge naturally but have to be constructed via the process of linking "self" to its perception of and interaction with the "other". [3] As the individual's and the group's identities are defined by beliefs and ideas about the way the world is and ought to be, which in turn constitute culture, political culture of a given society is shaped by those cultural beliefs and values. [4] According to Berger, "political-military culture refers to subset of the larger political cultures that influences how members of a given society view national security, the military as an institution, and the use of force in international relations." [4] Along the lines of the constructivists' arguments, the national identity of Japan has been defined by antimilitarism culture embedded in Japanese society since the end of World War II and this has been echoed in Japan's defense policy, which eschews direct involvement in fighting and limits SDF's roles to only noncombatant aspects.

In case of Japan, the country's so called pacifist constitution has thus far underpinned its peaceful security policy. Article 9 of Japan's constitution states that to uphold international peace "the Japanese people forever renounce war as a sovereign right of the nation and the threat or use of force as means of settling international disputes." For that purpose, "land, sea, and air forces, as well as other war potential, will never be maintained." However, the new interpretation of its constitution will allow Japan to send troops and equipment to aid allies in times of wars. This explains why the reinterpretation of Japan's constitution has raised concerns regarding a 180-degree change in Japan's national identity.

While Japan's national identity has appeared to be a peaceful nation since the end of World War II, Japan's military culture has been frequently challenged and gradually transformed under mounting pressure from both international environment and domestic political situations. These moderate changes have been demonstrated in the evolution of Japan's postwar security policy in the following three main phrases. 


\section{A. Merchant Nation and Rebuilding Economy (1945s $-1960 s)$}

In the immediate aftermath of World War II, the United States viewed that the top priority task was to completely demilitarize Japan and prevent reemergence of Japan's military. [5] Therefore, a new constitution was promulgated that included the famous Article 9. Shigeru Yoshida, the Japanese Prime Minister of the day, introduced what is called the Yoshida Doctrine, which heavily emphasized the nation's economic reconstruction while leaving Japan's defense to the United States under the U.S.-Japan Security Treaty. However, the advent of the Cold War, especially the outbreak of the Korean War, forced Japan to rethink its antimilitary policy. Under increasing pressure from the United States, Prime Minister Yoshida opted for "light rearmament". [6] This strategy proved to be so successful that Japan was eventually catapulted into the world's second biggest economy after the United States by the 1980s.

\section{B. Strengthening U.S.-Japan Alliance (1970s-1980s)}

Japan's economic boom in the 1960s resulted in Japanese economic and technological power close to that of the United States on many levels by the end of 1960s. It was the same time when Washington wanted Japan and its Asian allies to share more burden of their own defense responsibilities that many within Japan's industrial and political elites were also ready to translate Japan's newly emerging economic power into more explicit military power. [7] Nevertheless, the push for autonomous defense had been reversed following U.S. President Richard Nixon's reaching out to China in 1972. Those who had favored a more independent defense policy were now much more interested in China's massive market, leading to limit on military spending. In the mid-1970s when the threat of the Soviet Union was looming as American power appeared to decline in the Pacific following American defeat in Vietnam, Japan's ruling party leaders and bureaucrats chose to strengthen alliance with the United States. [7] For fear that it could be abandoned by the United States, which was increasingly concerned about burden sharing, Japan decided to increase its military spending as part of an attempt to reinforce U.S.-Japan alliance.

\section{Post-Cold War Era: Shifting Strategy and Drifting Identity (1990s-Present)}

At the beginning of the 1990s, there were a number of changes in both domestic and international environments the collapse of the Soviet Union, the burst of Japan's bubble economy, the eruption of the Gulf War, and the rising of China's economic power - that pose question to Japan's leaders and elites regarding how Japan would design security policy to properly response to those emerging challenges?

The 1991 Gulf War raised widespread criticism against Japan for its "checkbook diplomacy". Tokyo contributed US $\$ 13$ billion to aid the U.S.-led coalition forces sent to repel Iraq's invasion of Kuwait but failed to dispatch its personnel to the conflict despite unprecedented international pressure. The United States demanded that Japan make both financial and physical contributions but due to the constitutional restrictions, Japan could only make a financial contribution. Learning from this experience, Japan passed the International Peace Cooperation Law in 1992 enabling Japan to send not only its civilian personnel but also its SDF personnel to join
UN peace keeping operations. However, Japan's SDF personnel still faced difficulty in contributing significantly as the 1992 law imposed highly restrictive conditions on the SDF's roles and severe limit on the use of weapons by the SDF. The embarrassing experience was considered as one of the key factors leading to a shift in Japanese security policy in the post-Cold War.

The 1993-1994 North Korean nuclear crisis followed by the 1995-1996 Taiwan Straits crisis also required Japan to reconsider its defense needs and revision of the legal framework governing the SDF. In 1996, a joint U.S.-Japan security declaration was announced to make it more relevant to the post-Cold War environment. Based on this declaration, the U.S.-Japan Defense Cooperation Guidelines were then revised in 1997, enabling Japan to dispatch SDF personnel for noncombatant evacuation operations, support for the U.S. military, and inspections of ships in international waters in accordance with UN Security Council resolutions. [6]

Regarding domestic reasons as pointed out by Bhubhindar Singh, Japanese governments had been increasingly facing mounting pressures to reform the domestic constraints that had hindered Japan's more active role in international arena. This, as aforementioned, became apparent after the 1991 Gulf War and was accentuated by Japan's inability to deal with security threats at home in the events of Kobe earthquake and Aum Shinrikyo attack on Tokyo's subway in 1995. [8] Japan's prolonged economic stagnation coupled with the emergence of China's soaring economy in 1993-1996 was another blow to Japan's national identity as an economic superpower. This, as noted by Gilbert Rozman, in part drove Japan's rightwing politicians to seek for a redefinition of its national identity. [9]

The onset of the twenty first century brought Japan both unsolved problems from the last decade and newly emerging security challenges.

At the international level, the problems have appeared to revolve around China's rise, North Korean threats, and the possible U.S. drawdown. China's growing economic and military power has continued to concern Japan, whose Defence White Paper in 2000 first mentioned China as one of the major threats needed to be address. China eventually overtook Japan as the world's second-largest economy in 2010; and even before reaching that point, Beijing has thus far translated the country's affluence into military clout. On the one hand, Tokyo has been very worried about China's opaque defense spending and has made complaints about this on several occasions. On the other, the issues of controversial history textbooks, frequent visits to the Yasukuni Shrine by Japan's top politicians, territorial disputes over Senkaku/Diaoyu Islands have so far soured relations between China and Japan. The year 2005 marked the lowest point of Sino-Japanese relations for the first time since the normalization in 1972. Tens of thousands of Chinese protesters took to the streets in over a dozen cities across China in protest against Japan's bid for a permanent seat on the United Nations Security Council and a new Japanese junior school textbook. [10] The conflict between the two countries flared up again in September 2010 when a Chinese fishing boat collided with a Japanese Coast Guard vessel near the disputed Senkaku/Diaoyu Islands in East China Sea. The collision and the consequent arrest of the Chinese captain resulted in a major diplomatic strain in their bilateral ties and led to alleged China's halt in exports of rare earth materials to 
Japan. The already tensed relationship was deteriorated after Japanese government had agreed to buy some islands in the disputed Senkaku chain from a Japanese family in September 2012 in an attempt to nationalize disputed territory. The deal drew fierce response from the Chinese side which condemned Japan's action and also sent two maritime law enforcement ships belonging to the China Marine Surveillance to the islands in a show of strength.

On the issue of North Korean treat, Japan has often been frightened by provocative actions of Pyongyang. The first North Korean missile crisis started in August 1998 when Pyongyang fired a suspected missile over Japan, while the most recent event occurred in July 2012 when two ballistic missiles launched from somewhere in southwestern North Korea fell into waters separating Japan and the Korean peninsula.

The factor that accentuates the seriousness of Japan's security concerns is the possibility of the U.S. drawdown from East Asia. This concern seemed to be much more severe following the aftermath of the Soviet Union's collapse but has remained until now, even after President Barack Obama announced strategic pivot to Asia. The United States is currently attempting to transform its bilateral alliance in Asia from the old-hub-and-spokes model to a networked set of alliance relations, leaving Japan vulnerable if it insists on relying unilaterally on Washington for military protection. [11] Moreover, Obama's promise has so far proved to be more rhetoric than reality.

In short, there has been a growing realization in Japanese society that highly restricted military role based on the principles of peaceful nation is no longer legitimate in light of heightened international responsibility and evolving regional and global security environment in the post-Cold War period.

\section{ANALYSIS: WILL JAPAN’S NATIONAL IDENTITY CHANGE COMPLETELY?}

Given all challenges in the international security environment - China's growing military and economic clout, North Korean threat, uncertainty in the U.S.-Japan alliance, and territorial disputes in the East China Sea, Japan has been forced to adopt a more rational foreign and defense policy. However, does this necessarily imply that Japan has abandoned or is trying to shake off its antimilitarism culture?

According to Berger's argument, political-military cultures are not static entities but are vulnerable to social, economic, and political pressures. Cognitive beliefs about the world are constantly tested by actual events. Failures and surprises create pressures that can eventually lead to a reevaluation and modification of the culture. The process of culture adaptation, however, takes place only incrementally under normal circumstances in response to shifts in environment. Whenever significant new policies violating established norms and values are introduced, some particular forms of resistance from that given society should be observable. Dramatic or total transformation in culture due to rapid change in core beliefs and values is not impossible but only after they are "thoroughly discredited" and the whole society is under great strain [4], [12].

In case of Japan, we can see that while Japan's peaceful military culture has been maintained since the Second World
War and taken root in Japanese society, it has undeniably deviated from the origin to a moderate degree. This has been well reflected in the evolution of the nation's foreign and defense policies in tandem with newly emerging domestic and international pressures over time. Failure of Japan's checkbook diplomacy in the wake of the Gulf War pushed the country to reconsider and expand the SDF's security role. In view of North Korean threat, Taiwan crisis, China's rise, and fear of American withdrawal in the 1990s resulted in the renewal of the U.S.-Japan Defense Cooperation Guidelines in 1997, which in turn led to even broader responsibilities of Japan's SDF. With the escalating tensions with China over the matters regarding historical memories and territorial disputes in East China Sea, Tokyo's recent move to reinterpret its postwar constitution is not extremely striking and should not be over exaggerated though grave concerns among its immediate neighbors are inevitable.

One should be reminded that the country with huge economic size has consistently constrained its military roles within the scope that is narrowly allowed by the constitution. Moderate deviation has been observed but complete shift in antimilitarism culture is yet to be evident. Two factors have played an important role in checking any drastic drift in Japan's defense policy - Japanese society and the U.S.-Japan alliance. Soon after Prime Minister Abe has repeatedly called for reinterpretation of the postwar constitution, thousands of protesters took to the streets in Tokyo, rallying against it. In the latest protest just before the announcement on 1 July, thousands of demonstrators rallied outside the Prime Minister's office and official residence, demanding that Prime Minister Abe step back from the attempt to reinterpret the constitution. A poll conducted by the Yomiuri newspaper in the days after the announcement of his plan showed support for Abe administration fell to 48 percent, down nine percent from a similar survey in May. This finally led to Prime Minister Abe's decision to slow the process of revising a number of laws relating to the reinterpretation, with a hope that a longer debate period would help build public acceptance. [13] While putting pressure on Japan to play a more active role in their bilateral security arrangements, Washington has also made sure that Tokyo's move would not destabilize the balance or intensify tensions in the region. In April, when Prime Minister Abe expressed eagerness to seek the capability to attack sites in an enemy country used to launch ballistic missiles at Japan, Washington told its Japanese counterparts during bilateral meetings that it could not fully approve of Tokyo's plan to mention this in the bilateral defense guidelines, which the two countries plan to review by the end of this year [14].

\section{CONCLUSION}

In a foreseeable future, it is unlikely that Japan will return to a militaristic past as many may fear because that would require an extreme shock to Japanese society which consequently persuades the whole country to abandon its six-decade antimilitarism culture. To put it in a nutshell, the recent evolution of Japan's defense policy demonstrated in an attempt to reinterpret the constitution is a combined consequence of a shift in the country's security strategy and a 
moderate change in its national identity in a bid to better respond to changing international security environment in the post-Cold War rather than a thorough change of its national identity or a return to militarism. However, this moderate transformation in Japan's national identity is neither necessarily consistent with its national interests nor improvement in relations with Japan's neighbors who have sounded increasingly alarm over its latest move. Japan's policy makers in the postwar era were afraid of being dragged into its allies' conflicts, the worst case scenario that they had always tried to eschew and constitutional constraints had enabled them to do so, but Japan's new defense policy could enhance that possibility. To alleviate concerns and distrust among Japan's neighbors, it would be wise that Abe administration provide greater consultations and transparency for their neighbors about Japan's ultimate objectives. Due to the fact that Prime Minister Abe has not yet met President $\mathrm{Xi}$ Jinping since assuming the office in December 2012 as the bilateral ties between the two superpowers were tainted over historical and territorial issues In addition, amid Dokdo/Takeshima disputes and arguably Japan's inadequate apology for its military's sexual abuse in the past, Japan's relationship with South Korea has remained cold at best. The upcoming Asia Pacific Economic Forum (APEC) to be held in Beijing in November will provide Japan an opportunity to arrange talks with all relevant stakeholders for the sake of building better mutual understanding and gaining trust toward Japan's peaceful stance.

\section{REFERENCES}

[1] Japan Stages Military Exercises off Disputed Islands. [Online]. Available:

http://www.presstv.ir/detail/2014/08/19/375874/japan-holds-drills-off -disputed-islands/.

[2] R. Li. (July 2013). National identity and changing great power relations in the Asia-Pacific: is a Cold War emerging?". [Online]. Available: http://www.theasanforum.org/national-identity-and-changing-great-po wer-relations-in-the-asia-pacific-is-a-cold-war-emerging/

[3] D. Abrams and M. A. Hogg, Social Identity Theory: Constructive and Critical Advances, London: Harvester, 1990.

[4] T. U. Berger, "Norms, Identity and National Security in Germany and Japan," Culture of National Security: Norms and Identity in World Politics, New York: Columbia University Press, 1996, pp. 317-356.
[5] Y. Kawashima, Japanese Foreign Policy at the Crossroads: Challenges and Options for the Twenty-First Century, Washington, D.C.: The Brookings Institution, 2003, ch.1, p. 6.

[6] H. Tanaka. (February 2014). Japan's Debate on Constitutional Reinterpretation: Paving the Way for Collective Self-Defense. [Online]. Available: http://www.jcie.or.jp/insights/9-1.html

[7] M. J. Green, Japan's Reluctant Realism: Foreign Policy Challenges in an Era of Uncertain Power, New York: Palgrave Macmillian, 2003, pp. 15.

[8] B. Singh, "Japan's post-Cold War security policy: Bringing back the normal state," Contemporary Southeast Asia, vol. 24, pp. 82-105, April 2002.

[9] G. Rozman, “Japan's quest for great power identity,” Orbis, vol. 46, no. 1, pp. 73-91, winter 2002.

[10] J. Zhang, "The influence of Chinese nationalism on Sino -Japanese relations," China-Japan Relations in the Twenty-first Century, 2007, pp. 15-34.

[11] Reinterpreting Japan's Constitution. [Online]. Available: http://www.forbes.com/sites/sheilaasmith/2014/07/03/reinterpreting-ja pans-constitution/.

[12] For more Discussions on Antimilitarist Social and Legal Norms within Japanese Society, From a Peaceful State to an International State, Abingdon, Oxon; New York: Routledge, 2013, pp. 26-29, 71-72.

[13] M. Inoue and N. Gough. Polls Slow Japan's Plan to Revise Constitution. [Online]. Available: http://www.nytimes.com/2014/07/10/world/asia/polls-slow-japans-pla n-to-revise-constitution.html?_r=0.

[14] Japan won't Express Intention to Gain Ability to Strike Missile Sites, Source Says. [Online]. Available:http://www.japantimes.co.jp/news/2014/09/01/national/japa n-wont-express-intention-gain-ability-strike-missile-sites-source-says/ \#.VAzJyfnV8e4.

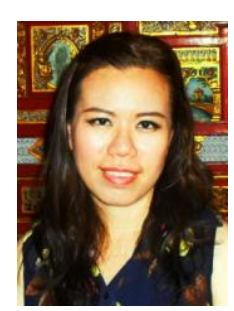

Nutthathirataa Withitwinyuchon was born in Phuket and brought up there until she joined Thammasat University in Bangkok in 1995. Four years after she finished her bachelor's degree in Japanese language, she got a scholarship from Asian Development Bank (ADB). She received her master's degree in international relations in Japan.

She had been working as a journalist for many years for several media including Japan's Nippon Television and China's state-run media - Xinhua News Agency - before receiving a scholarship to start her $\mathrm{PhD}$ in International Relations at the University of Otago in New Zealand at the beginning of March 2014. Her research interests are mainly about Japan's foreign policy and security in East Asia, while her research topic at the University of Otago is about Sino-Japanese relations. 